\title{
Theatrical Complicity as a Medium of Emancipation
}

How do we find a solution when we ourselves are the problem? This is the question posed by two contemporary performances that frame the spectator as an accomplice in the exploitation and representation of suffering and violence in a globalized and mediatized world: Sálo (2010), based on Pier Paolo Passolini's film by the same name (1975), by the Danish performance group SIGNA in cooperation with Teater Republique; and the Royal Court Theatre's production of Tim Crouch's The Author (2009), co-directed by Karl James and a smith. By applying the systems theory of Niklas Luhmann, the two performances are analysed and compared as elaborately structured games of observation, where the spectators are made to observe their own acts of spectating as complicity in the reproduction of violence caused by theatrical representation. Jaques Rancière's paradox of the spectator and Josette Féral's concept of theatricality are re-described in a systems theoretical perspective in order to show how the theatrical attribution of guilt to the spectator can work as a medium of emancipation. The explication of the different dramaturgies makes it possible to distinguish between how self-righteous, self-examining, progressive and 'tragicist' conceptions of emancipation are given form in different ways and measures in the two performances. In this way, the article aims to contribute to the qualification and expansion of a critical discourse on participatory theatre and performance beneath the loosely defined horizon of a modern theatre of emancipation.

Keywords: Tim Crouch, Signa Köstler, Jaques Rancière, Niklas Luhmann, Josette Féral, spectatorship, theatricality, tragicism, political theatre, participation, emancipation.

BIOGRAPHY

Thomas Rosendal Nielsen, PhD, is associate professor at the Department for Aesthetics and Communication, University of Aarhus. His doctoral dissertation was about interactive dramaturgy (2011). Rosendal Nielsen is editor of the Danish academic journal Peripeti - tidsskrift for dramaturgiske studier, and of the Nordic journal of applied drama, DRAMA - nordisk dramapedagogisk tidsskrift. Currently, he is researching the fields of participatory theatre and applied drama. 


\section{Theatrical Complicity as a Medium of Emancipation}

\section{THOMAS ROSENDAL NIELSEN}

In his seminal essay, The Emancipated Spectator, ${ }^{1}$ the French philosopher Jacques Rancière points out the irony of what he calls the paradox of the spectator: a fundamental and implicit contradiction in the avant-garde traditions of theatre following Bertolt Brecht and Antonin Artaud. The paradox that Rancière observes is that, by definition, theatre implies spectators, but the poetics of avant-garde theatre demands "a theatre without spectators, where those in attendance learn from as opposed to being seduced by images; where they become active participants instead of passive voyeurs". ${ }^{2}$ This paradox resonates in the participatory agendas of the so-called performative turn ${ }^{3}$ of the 1960s and the interactivity hype of the digital revolution around the turn of the twenty first century. ${ }^{4}$ The consequence of this paradox, in Rancière's terms, is that "theatre is presented as a mediation striving for its own abolition". 5

One of the interesting things about paradoxes is that, even when they are disclosed as such, they do not tend to stop communication. Instead, they provoke a shift in the mode of observation, which multiplies the possibilities for further communication and thereby necessitates choices. ${ }^{6}$ On the level of artistic practice, the paradox of the spectator calls for choices on how the abolition of spectacle should be realized through theatrical communication; e.g. should the audience step onto the stage, should the performer step into the auditorium, or should a common space for all participants be created (to name but a few obvious possibilities)? On a theoretical level, the paradox calls for a choice of perspectives: should the paradox of the spectator be interpreted as a blind alley of a utopian twentieth century avant-garde, as a sharp and irreversible (performative) turn on the road towards the non-theatre of the future, or as a point of bifurcation in a modern tradition of a theatre of emancipation?

I favour the latter position, acknowledging Rancière's critique of the stultifying implications of the agenda of activating the audience, but without drawing the possible conclusion from his essay that we should settle for a theatre were "spectacles are merely spectacles". ${ }^{7}$ If this proposition were to be taken literally, this would lead us to dismiss some of the most innovative tendencies in contemporary performance (participatory theatre). In any case, I think we could learn more from Rancière's objections by turning them into a more critical sensitivity for the different forms of emancipation in artistic practices.

In the two cases analysed below, we are faced with theatre that reconfigures the conventional audience-performance relation in order to reveal the complicity of the spectators in the 'crime of spectatorship'. In this regard, both performances make up perfect examples of Rancière's paradox of the spectator and the problem of stultification it entails. At the same time, however, they give form to quite different conceptions of emancipation through their specific dramaturgies, i.e. by the way they structure and give form to (inter)action. I believe the aim for a dramaturgical analysis should be to explicate the value differences of such conceptions rather than simply rejecting them on the basis of their paradoxy. 
In my dissertation, ${ }^{8}$ I argued that a systems theoretical perspective, based on the work of Niklas Luhmann, is suitable for this kind of analysis. I will not present an extensive recapitulation of the approach here, but point out the necessary preconditions for the present analysis. The focal point for a systems theoretical approach is the observation of observations (second order observation). The idea is to observe how observations are observed (by a system - which means nothing other than 'an observer'). Observation in the context of this theory should not be confused with perception. The concept of observation simply, abstractly and precisely designates the production of a distinction between two sides of a difference and the indication of one of the sides. The observed unity of distinction and indication is called a form. Anything that is distinguished from everything else is thus a form: an actor's body, a dramatic role, a colour on the wall, a demarcation of space, a theme, a beginning, a word. These are all forms in the exact sense that they are observed by an observer as something particular in the horizon of everything else, and through this specific operation, they give form to further observation.

A work of art - even an ephemeral and variable one such as a theatrical performance - consists of a highly complex interplay of forms. The work of art is thus a complex programme for observation. It structures observation in specific, but variable ways, in some cases (such as in interactive works of art) the structure can change and adapt to the situation of observation, but even in such cases, these changes only happen recursively, i.e. on the basis on what is already observed and given form in the work of art. Therefore, the general question for this systems theoretical approach to performance analysis is: what kinds of observations are made possible by the complex interplay of forms in a given performance.

Of course, most works of art present us with a surplus of possibilities for observation, and therefore an analysis cannot simply map all the possibilities of observation in a given work. In the observation of observations we will have to select and trace the development of some forms rather than others. The title of this article marks the three most important forms (Leitdifferenzen) that structure the analysis below. The emphasis on theatrical(ity) marks an analytical interest in how the distinction and unity between reality/fiction takes a prevalent function in the way observation is structured and value is ascribed to forms in the two analysed performances. The distinction 'medium/form' will be given the least explicit attention in the analysis, but it signifies the basic assumption that works of art through their forms serve as media for observation and thus create conditions for processes outside their immediate material reality. ${ }^{9}$ In this way, the experience of a theatrical performance mediates (among other things) the construction of our personal and social identities - including the participants' observation of themselves and others as e.g. guilty or free. Finally, the distinction between complicity and emancipation provides the main thematic focus of the analysis: in short, both performances give form to processes of observation in which we should observe our own complicity in a general 'spectacle of violence' in order to emancipate ourselves (and the victims of this general spectacle) through the tragic recognition of our own guilt.

The two performances do this differently and thus offer different forms of emancipation in the tradition of, what I loosely call, a theatre of emancipation. The purpose of the present analysis is to make this difference clear, because it gives us an idea of how theatre can serve emancipation through paradoxical strategies that involve not only positive experiences of empowerment, but also negative attributions of guilt. Freedom comes with a price so to say, and both the price and the gain are different in the two cases. When I evoke the idea of a theatre of emancipation, I do not mean to suggest any particularly new trend or a more narrow line of development (e.g. following Augusto Boal's theatre of the oppressed), but rather the general horizon of a modern theatre that, since the enlightenment, has aimed to further the education or creation (Bildung) of a (global) community of free people. It is on the basis of this horizon that I will discuss the strategies of the two particular cases in question.

Both Sálo (2010) by SIGNA and The Author (2009) by Tim Crouch et al. have been the subject of relatively extensive attention in both public and academic media. ${ }^{10} \mathrm{I}$ attended both performances, and in the two following analysis I will observe the 
'game of observations' made possible by the two performances.

\section{MISERY TOURISM}

The launch of Salo in the late winter of 2010 provoked an outraged debate about the ethics of theatre in the Danish newspapers. The performance group SIGNA, led by the Danish artist Signa Köstler, had made an environmental production (to use Schechner's old term ${ }^{11}$ ) of Pier Pasolini's Salo, or The 120 Days of Sodom (1975), which was in turn based on the Marquis de Sade's book of the same name from 1785. The audience members individually entered a large manor house in a residential area in Copenhagen. There, they found themselves visitors of a libertine society ruled by four masters and their staff, who tortured and abused a group of enslaved young people in front of the audience. This was controversial enough in itself, but what really riled the debate was Signa Köstler's public accusation of the audience for being cynical misery tourists: "More than anything else, I am scared by the blasé attitude of the spectators: the superior indifference to the silent despair." ${ }^{2}$ This triggered numerous responses of offence from spectators. Some pointed in defence to the situation's confusing blur between fiction and reality, while others, in contrast, referred to the blatant theatricality of the production: "Strange condescending attitude to the audience. People know very well that they are watching a play and not a real orgy of violence. Should the audience also interfere when the heroes of Avatar are in trouble?"13

At first glance, the Sálo production is an obvious example of the Artaud line of theatrical avant-garde, being a theatre of action that attacks the passivity of the spectator and sacrifices the performers in order to produce a violent and sensual impact on the audience, reaching beyond mere intellectual sensibility to a 'living force'. ${ }^{14}$ Köstler's utterances to the press even echo Artaud's and Guy Debord's ${ }^{15}$ critique of the mass media spectacle, claiming the necessity of penetrating the sweet torpor of entertainment with the help of more radical means of (re)presentation in order to reach true intimacy and collective responsibility. ${ }^{16}$

In this way, by moralizing on the passivity of her audience, Signa Köstler readily adopts the role of the stultifying pedagogue identified by Rancière: "Even if the playwright or director does not know what she wants the spectator to do, she at least knows one thing: she knows that she must do one thing - overcome the gulf separating activity from passivity." ${ }^{17}$ Even the humble artist who doesn't wish to prescribe solutions for his audience reinstates the implied inequality between spectator and performer by replacing the difference between passive and active subjects with the difference between they who are to be activated and they who are to activate the others.

However, the theatrical game of observations facilitated by the performance is more complicated than what was revealed by the public debate.

It is a straightforward and popular way of describing participatory theatrical experiences to say that the difference between fiction and reality (and consequently between art and life) becomes blurred. In many cases, this is true from a phenomenological point of view, but, as a dramaturgical description of the performance, it is, at best, imprecise. The present two cases testify to this, as the 'blurring' has both different causes and effects, which we are able to describe more accurately.

In Sálo this problem is especially important because - as seen in the quotations from the debate above - the diverging observations on how the theatrical fiction is constituted is used as both an argument for the attribution of guilt to the other party and as an excuse for oneself: "we were just playing", "they were just watching", "we were just watching a play", and so on. This is made even more intricate by the dynamics between the individual ways the audience members related to the performance and to each other, and by the fact that these ways of relating were observed as part of the performance by both performers and other audience members.

The question for this analysis is thus: what kinds of patterns for distribution of guilt are enabled by the observation of theatricality in the interaction between performers and audience members and in the internal interaction between audience members? 


\section{THEATRICALITY}

This requires a clarification of the somewhat ambiguous concept of theatricality. ${ }^{18}$

Josette Féral, in her foreword to SubStance \#98/99, describes theatricality as a complex process of disjunction and unification actualized through the gaze of a spectator that cleaves space, reality and action into an unstable unity between everyday space/representational space, reality/fiction and intuitive/symbolic action. ${ }^{19}$ To analyse theatricality in performance is then to describe the conditions, interactions and consequences of this mode of observation and how the possibilities for communication $^{20}$ are altered and modified by the observation of reality and fiction as a unity. Féral's theory is explicitly based on Kantian epistemology and, as my approach is based on a systems theoretical concept of observation, a few modifications are needed to the otherwise suitable definition.

Firstly, I consider the observation of a distinction between fiction and reality as indispensable, but I view the cleaving of space and the cleaving of action as supplementary and interchangeable instantiations or indicators of this critical difference. The observation of the distinction is paradoxical, because the difference between reality and fiction is observed as a unity. This distinguishes theatrical fiction from other kinds of fictions in which the fictional reality is external to the reality conveying it (the typical example would, of course, be literary fiction).

Secondly, I think it is heuristically necessary to distinguish between 1) the spectator as a role; the role of audience member, who either does or does not infer theatricality from what he or she observes and 2) the observer of theatricality; meaning the process of observation that projects the distinction between fiction and reality onto a material. The spectator is a social function in specific situations of communication. The observer of theatricality is the system (of consciousness or communication) that projects the distinction between fiction and reality onto a material. Thus, not all spectators observe theatricality and not all observers of theatricality have the role of spectators. ${ }^{21}$ The actor, for one, is an observer of theatricality to the extent that they need to observe a distinction between fiction and reality in order to act, but that does not necessarily confer the role as spectator to the actor.

Thirdly, the observation of theatricality is not conceived here as a purely cognitive and perceptual event (in a transcendental philosophical tradition ${ }^{22}$ ), but as the production of a form in the medium of meaning ${ }^{23}$ that unfolds simultaneously in processes of consciousness and processes of communication. ${ }^{24}$ In other words, the observation of theatricality is as much a social operation as it is a cognitive operation. In a systems theoretical perspective, the performance itself, as an interaction system, is an observer of theatricality. (Remember that an observer in systems theoretical terms is not a subject, but simply a system, a structured process of e.g. communication or consciousness, that produces distinctions, cf. above).

In this way, we arrive at a more condensed and less 'Kantian' idea of theatricality: theatricality is the paradoxical unity of fiction and reality (re)produced by an observer. This paradox (not to be confused with Rancière's paradox of the spectator) consists in the unstable unity between two oppositions, working on two different levels. On the first level, a unity is observed in the difference between reality and not-reality ${ }^{25}$ (i.e. fiction). Laurence Olivier is at the same time not Hamlet and not not Hamlet to use Schechner's ${ }^{26}$ classical example. On the second level, the paradox is double, because it also designates the concurrency of observing the fiction as reality, and observing fiction as not reality. In systems theoretical terms, this can be described as an unstable unity between first and second order observation.

First order observation only sees what it sees, i.e. the one side of the form fiction/reality (Hamlet or Olivier). Second order observation sees the paradoxical difference contained in the form of the first order observation and thus both sides of the paradox (Hamlet and/or Olivier). Without the second order observation, theatricality would be pure deception. ${ }^{27}$

This second order observation might be latent (willing suspension of disbelief) or dominant (Verfremdung), but, in both cases, theatricality implies a unity between first and second order observation and, thus, the possibility (and necessity) of shifting emphasis between them. In order to render these 
paradoxes explicit in the above provided definition, we could restate the formulation: theatricality is the observation of observing something as something it is not.

For the practice of performance analysis, this leads to the questions: when and how is this unstable unity between fiction and reality produced? How is it stabilized or destabilized through the theatrical communication and with what kind of invitations to first and second order observation? In addition, in the particular cases of the present article, what consequences do the specific forms of theatricality have for the attribution of guilt?

\section{EMANCIPATION AS BLAME GAME}

Returning to Saló, we can now analyse how the observation of theatricality can be used as both an excuse for oneself and an accusation of the other by both spectators and performers.

The initial evocation of theatricality is carried out unambiguously in the way the audience is received by the performance: you buy a ticket and present it at the door; you are received by actors addressing you in character, explaining different rules to you (e.g. you are not allowed to laugh inside, you can only speak in English or in German); the interior decoration of the house and the clothes of the performers are clearly stylized and in sharp contrast to the surrounding neighbourhood and the quotidian clothes of the audience members. A kind of realism can be observed in the immersive representation of depravity, but the observation of theatricality is incited by the initial framing of the performance space. Then, upon entering, two aesthetic forms destabilize the observation of theatricality: the use of real violence and abuse (some of it carefully rehearsed) and the vaguely defined theatrical role of the audience participant.

When the young performers are physically tortured or made to masturbate in front of the audience (even if it is sometimes well rehearsed), it destabilizes the observation of reality as fiction, triggering a shift to the dominance of second order observation: the observer is made to observe that this is both fiction and not-fiction. ${ }^{28}$ The distinction between fiction and reality does not collapse by this, but, when switching back to first order observation, the observer has to decide whether he or she wants to relate to what is happening as if it is fiction or as if it is reality. The as if quality remains; there is no way to return to a naive observation of reality as reality and fiction as fiction.

This pseudo-naïve return can only take place rhetorically: when Signa Köstler in the press blames the audience for not interfering and the audience members defend themselves by pointing out the theatricality of the performance, Köstler is pretending that there is no fiction at all or that the fiction is simply reality. The audience, in turn, uses the possibility of switching to the 'as if just fiction' side of the observation, attacking the premise of the accusation. Conversely, in order to anticipate critique from people who observe the fiction as reality, Köstler herself switches to the opposite side, observing fiction as if only fiction, and explains the effort the actors make in playing a role and the difficulty of providing a sufficiently truthful representation of violence. ${ }^{29}$ Thus, in this case, the 'blur' of fiction and reality is used to ascribe innocence to oneself (as performer or as spectator and guilt to the other.

The unstable theatrical paradox in this case makes the game of observations into a blame game where the other is accused for not understanding the real difference between fiction and reality and, thus, for not acting accordingly. In Rancière's perspective, both parties get to play the role of the stultifying pedagogue, who knows what the other does not know.

This situation becomes even more intricate when we take a closer look at the theatrical relations between the audience members inside the performance. While it is very clear from the start that the performers are playing theatrical roles, the framing of interaction is ambivalent when it comes to whether the roles of guests in the house are to be observed as theatrical roles (like in a dramatic role play) or simply as the roles of visitors at an exhibition (as social convention might imply). This lack of clarity allows for a more dynamic negotiation of spectator positions between the audience members during the performance. The individual audience member has to decide whether or not to observe the other audience member as playing a fictional 
role, and, in many cases, to take the uncertainty of this issue into account when interacting with him or her. The same applies to the observation of one's own actions, and the observation on how other audience members react to one's own actions. This allows for an interesting and complex game of misunderstandings.

This is perhaps best illustrated by an example. I was a guest of one of 'the Masters', and after having spent a couple of hours in the house, I found myself sitting in a room with this Master (called the Magistrate) and another guest, having a conversation about music. The other visitor happened to be a musician, which made the Master so enthusiastic that he decided to arrange a concert in honour of my fellow guest. The Master gathered everyone in the dining hall and placed the musician by his side. The other guests, myself included, were invited to stand along the walls while the choir of 'Children' (the young enslaved people) stood half-naked in a group among the tables. A girl played the piano in the corner and the choir was conducted by one of the Children, 'Franchino', a slim boy with long hair and a beautiful voice. The song seemed well rehearsed, but Franchino frequently shouted corrections to the girl at the piano, until the Master stopped the singing in a fit of rage and started beating the girl with a whip very hard for a length of time until she fell down from the stool and lay crawling on the floor, completely red from the beatings. Nobody intervened.

I looked around at my fellow audience members to see how the expressions on their faces fitted Köstler's description of "superior indifference" and noticed a complex pattern of looks. Some were looking at the floor or in the opposite direction to the action with an expression that could suggest suppressed pain, embarrassment as well as indifference. Some were looking angry, some were looking interested, and some were even smiling uncomfortably. Then, some were - as I was - watching other people's faces with curious, concerned, indignant and even condemnatory expressions. The Master went back to the choir, the song continued and culminated as the Master was being 'taken from behind' by one of the guards. When the concert ended, the musician, the guest of honour, had left.

The exchange of looks in this example was symp- tomatic of the interaction between the audience members during the performance - the obscene action and the unstable theatricality was a trigger for a game of moral positions between the audience members. I am able to observe the other as shameful, brave, cynical, decent, moralising, etc. I cannot hide from being observed as occupying one of these positions too, but I can choose to play with the position, to resist it, to put the other in a more uncomfortable position than myself. I can, as a group of women did during my visit, confront my fellow audience members with moral superiority - "How can you watch this? Do you enjoy this?" - and I can avoid any such confrontation by playing the intellectual superior art critic who has 'seen through it all', even by playing along and hiding behind the fiction: "Yes, I really do enjoy this." The ambiguousness of the theatrical framing allows me to escape any moral accusation by shifting to the opposite side of the difference when it is convenient: "I was just watching a play. I was just playing." What I cannot do is suspend the game of ambiguous theatricality. The only true resistance to the violence and oppression in the installation - if this request is to be taken seriously - is to leave as the musician did, or not to show up at all.

However, this is not theatre of the oppressed (Boal). The space for reflection and action is outside the performance. It is perhaps an attempt to create a 'theatre of desperation', where the feeling of powerlessness and complicity in the violence should propel us towards ethical responsible thought and action after the experience. But the Sálo installation also tends to become a 'theatre of self-righteousness'; not that a more self-critical response is impossible on a psychological level, but the blame game instigated by Köstler's accusations and the blatant moralizing agenda seemed to provoke more defensive responses. Self-righteousness can, nevertheless, also be observed as a form of emancipation.

\section{A PRIVATE CLUB FOR THE DEPRAVED}

The Royal Court Theatre's production of Tim Crouch's The Author (2009) ${ }^{30}$ dissolves "the paradox of the spectator" into something like an inverted mise en abyme: the audience within the audience 
within the audience and so on. The Author is perhaps the perfect example of a performance that "challenge[s] the opposition between viewing and acting" 31 in a way that is not only radical and original in its self-reflexive game of observations, but symptomatic of our time.

On a formal level, the performance employs a range of contemporary artistic devices: strictly-framed audience participation, convergence between fiction and reality, pseudo-biographical narrative, 'post-postmodern' irony and a persistent emphasis on the situation and mediality of the experience itself.

The performance plays out the (fictional) story of an in-yer-face-theatre production about incest, in which the director abuses the actors' political and personal engagement in the theme of the production resulting in disillusion and trauma, a violent attack on an audience member by one of the actors, the disclosure of the hypocrisy of all involved members of the production - including the audience and finally in the suicide of the author-director. In the controversial main scene of the real production, the audience is submitted to hearing the author (Tim Crouch in the role as 'Tim Crouch') confess how he, after the premiere of the production. masturbates to child pornography with a baby sleeping by his side. The theatre space is completely darkened throughout the scene, leaving us with no way to leave the auditorium and no other possible focus of attention than the voice of Crouch and perhaps a few protesting fellow audience members. This scene especially led to a debate somewhat similar to the one about Saló in Denmark. ${ }^{32}$

As in the previous example, the performance communicates through a form of theatricality that attributes guilt to the audience. An initial description of the theatrical conventions applied will identify a 'thin' fiction (a marginal displacement of time and space), established by the marking of the auditorium as 'stage'; two groups of audience seating are placed in front of the other without any other marked theatrical space. The theatrical space is only established by the acting of the four performers, acting in a style somewhere in between simple acting and not-acting in Michael Kirby's famous continuum. ${ }^{33}$ They present themselves with their own names and engage in dialogue, referring to the actual situation, the actual audience members and the actual place of the performance ${ }^{34}$ (Royal Court Theatre, Jerwood Theatre Upstairs).

This thin fiction is unfolded through the pseudo-biographical narratives of the actors that make plausible, yet fictional, claims to recent events in the immediate area of the performance. All this creates a minimal distance between fiction and reality, but a distance nonetheless; although it may seem unclear where the fiction starts and the reality begins. Whereas SIGNA's Sálo manifested a very clear demarcation of an alternative reality, making it possible to play on the indeterminacy of whether or not actions (or lack of action) should be observed as part of the fictional reality, The Author establishes continuity between reality and fictionality in a form that could best be described as a Möbius band. The inside (of the fiction) is in the perpetual process of becoming the outside (of reality) and vice versa, with no definitive mark of transition.

This process is exactly a process of theatrical observation; a process of observing a (minimal) distance to the presented situation through the distinction between fiction and reality. However, in this process, the theatrical observation perpetually encounters the spectator centre stage as the mode of presence from which it is distancing itself and as a mode of distance that is inescapably present. Theatrical observation turned on the role of the spectator thus evolves into a prison of self-reflection; a kind of narcissism where the spectator is caught in a distressing engagement with his own image, unable to overcome the distance between self and projection of self (like the hell proposed by Sartre in No Exit, 1944). The spectator is trapped in the imperfect reflection of himself being trapped in the imperfect reflection of himself etc.

The theatricality of The Author quite literally exemplifies Rancière's description of theatre as "a mediation striving for its own abolition" 35 as it almost collapses the theatrical situation into the act of spectating which is in turn presented as a sin: as the reproduction of the violence it claims to oppose. In this case, however, the abolition is incomplete, it perpetually and shamefully reproduces itself in the process. It gives form to the observation of the rep- 
resentation of violence as the rise and fall of critical ambition, leaving a 'ground zero' for either the rebirth of political theatre or the reconciliation with the imperfection of the world - ideally both at the same time. It is this junction in the constitutive ide$\operatorname{ology}^{36}$ of the performance - between a modern rationalist desire to confront and overcome suffering, inequality, ignorance, etc. and a premodern tragic recognition that these conditions are repeatedly reproduced by the means that is meant to remove them - that comprises the specific form of emancipation in this production.

The tragic current can be traced in the development of all four characters and is explicitly stated in 'Tim's' final monologue, given just before he theatrically commits suicide: "I thought about taking out my eyes. At first, I thought that would be the thing to do. The offending articles. Ha ha. The guilty party." (p. 58) The following "death of the author" (p. 59) is an ironic act of repentance in the narrative, but it functions as symbolic sacrificial ritual in the theatrical event. It counts as the sacrifice of the tragic hero, the dismemberment and ritual consumption of the embodiment of Dionysus, through which the audience becomes a community. ${ }^{37}$ Nevertheless, it is a communion based on Christian rather than Greek mythology: the Author sacrifices himself instead of (and in front of) the 'offending articles', the eyes of the beholder (the Oedipal reference obviously counts as a metonym for the audience), and bears the sins of the community, calling for their contemplation on the original sin of spectatorship.

'Tim' is in this way the double of the audience: the sin of the reproduction of unbearable images (p. 31) is perfectly exchangeable with the act of watching them. Guilt is attributed to the audience through the collapse of the opposition between acting and viewing, made observable through the complex mode of theatricality framed by the performance. The monologue (p. 46-7) of 'Adrian', the audience member in the narrative, marks both the tragic turn and the moment of insight in the dramaturgy as he explicitly discloses the premise of the play through enraged irony: "It's such an education! Isn't it? Isn't it, ? How far have those Maltesers gone? And nobody knows! Nobody knows! The cars and buses go round and round outside and none of them have any idea. No idea at all. That we're here, in here, safe in here, enjoying our Maltesers and our bum sex. It's a private club for the depraved!! Don't you think, ___ There's no danger of it going any further because we're all consenting adults. All of us, all us mother-fucking cunts!!” (p. 47).

The self-ironic stance of the performance incites the same Möbius-like process of observation as the framing of theatricality described above. We are invited to perpetually oscillate between the two sides of the double negation of the ironic trope without a stabilising gesture to establish which side is sincere. Again, we are left with the need to choose perspectives in the face of paradoxes: it is "such an education", but it is not; we are depraved, but we are not, etc. This ambivalence is the main vehicle for the didactic gesture of the performance. At this point, The Author is more radical in its critique of 'the spectacle' than Sálo, because it leaves no safe spot, neither in the position of the one who acts nor the one who watches, from where a moral judgment can be executed. ${ }^{38}$ It is this pitiless and uncompromising attribution of guilt to one and the same position (the actor is the spectator, the author is the audience, and vice versa) that constitutes the sceptic and yet didactic emancipatory gesture of the performance.

\section{THE EMANCIPATED SPECTATOR REVISITED}

In SIGNA's Sálo, the opposition between acting and viewing is perpetually reproduced and observed, attributing guilt to only one side of the distinction (spectating) and virtue to the other (acting), thereby affirming individual responsibility and the possibility of moral improvement. In Rancière's terms, the dramaturgy of Sálo enables a double process of stultification where performers and audience alike can project ignorance and passivity to the other in order to affirm their own superiority. This self-righteous empowerment, I argue, is the basic form of emancipation made possible by the participatory dramaturgy of Sálo. In the Royal Court Theatre production of The Author, the difference between acting and viewing is perpetually folded into the other, creating a self-reflexive form of theatricality which is used to frame the observation of complicity between per- 
formers and audience in the 'original sin' or 'tragic mistep' of making/watching reproductions of violence. In this way, the specific form of emancipation in The Author is enabled by an appeal to both the possibility of progress through critical self-reflection and to the necessity of some kind of acceptance or forgiveness of our imperfections.

The point is that the tradition of a theatre of emancipation and its avant-garde poetics of participation is not bound to turn into its opposite: stultification. Rather, it is the avant-garde vocabulary, insisting on 'the blurring of art and life' and the distinction between passive spectator and active participant, which is inadequate to grasp the subtle and important differences between the forms of emancipation that theatrical performances have to offer.

In a broader perspective, the occupation with moral hypocrisy in these two performances, and the almost strained attempt to find a position from where to criticize society from within, can be seen as attempts to establish an appropriate critical discourse for a 'post-political' age ${ }^{39}$ where there is no moral safe ground (at least in the western world). What we see here is the dramaturgy of Hamlet's 'Mousetrap' with the audience in the role of Claudius. Certainly there is an intention of evoking responsibility on the other side of desperation ${ }^{40}$ or "creating an imperfect act of love and hope" (as Crouch writes in the final lines of the text), but any such act is posited on the other side of an unforgiving act of self-examination. 


\section{NOTES AND REFERENCES}

1 Jacques Rancière, The Emancipated Spectator, Verso, London 2009, pp. 1-23.

2 Ibid., p. 5.

3 Erika Fischer-Lichte, Ästhetik des Performativen, Suhrkamp Verlag, Frankfurt am Main 2004.

4 Cf. Interactive Dramaturgies: New Approaches in Multimedia Content and Design, Heide Hagebölling, ed., Springer Verlag, Berlin 2004.

5 Ibid., p. 8.

6 These theoretical observations are informed by Niklas Luhmann's systems theory, cf. e.g. Niklas Luhmann, Einführung in die Systemtheorie, Carl-Auer-Systeme Verlag, Heidelberg 2004. On paradox, cf. p. 88.

7 Rancière, op. cit., p. 23.

8 Thomas Rosendal Nielsen, Interaktive dramaturgier $i$ et systemteoretisk perspektiv (Interactive Dramaturgies in a Systems Theoretical Perspective), unpublished $\mathrm{PhD}$ thesis, University of Aarhus, Aarhus 2011.

9 Cf. Niklas Luhmann, Die Kunst der Gesellschaft, Suhrkamp Verlag, Berlin 1995, p. 165ff, and Nielsen, op. cit., p. $95 \mathrm{f}$.

10 About The Author cf. the special issue of Contemporary Theatre Review, vol. 21, no. 4, Stephen Bottoms, ed., 2011. About Sálo cf. Laura Luise Schultz, "Overskridelsesæstetik og publikumsinvolvering i SIGNA's Saló" in peripeti.dk, 10 August 2010 (accessed 2 July 2015), Kim Skjoldager-Nielsen, "Signas Saló: Affekt og non-etisk katatsrofe" in Peripeti, no. 17, 2012, pp. 2938.

11 Cf. Richard Schechner, "6 Axioms for Environmental Theatre" in The Drama Review, vol. 12, no. 3, 1968, and Arnold Aronson, The History and Theatre of Environmental Scenography, UMI Research Press, Ann Arbor, Michigan 1981.

12 Ditte Lilholm, "Chokteater: Passivt publikum er skræmmende" in Politiken, 5 February 2010 (my translation).

13 Anders Frisk to Politiken in Anders Hjort, "Ondskabens bordel er jo bare teater" in Politiken, 5 Feburary 2010 (my translation).

14 Antonin Artaud, The Theatre and its Double, Grove Press, New York 1958 [1938], p. 84ff.

15 Guy Debord, Society of the Spectacle, Rebel Press, London 2004 [1967].

16 Cf. Teater Republique, "Hvorfor Saló?", press release, December 2009 , p. 2. See also the video report and interview with Signa Köstler made by the Danish news- paper Politiken, 3 February 2010: <http://politiken.dk/ poltv/ibyen_dk/ibyen/ECE893168/tag-del-i-sex-voldog-ydmygelser-paa-oesterbro/> (accessed 8 May 2012). The video also gives a good impression of the theatrical style of the performance-installation.

17 Rancière, op. cit., p. 12.

18 Cf. Erika Fischer-Lichte, "Introduction: Theatricality: a Key Concept in Theatre and Cultural Studies" in Theatre Research International, vol. 20, no. 2, 1995, p. 85ff; Thomas Postlewait, Tracy C. Davis, “Theatricality: an Introduction" in Theatricality, Cambridge University Press, Cambridge 2003, pp. 1-39; Peripeti - tidsskrift for dramaturgiske studier: Teatralitet, no. 7, E. Exe Chrisoffersen, ed.; Richard Schechner, Performance Theory, Routledge, London, New York 2003.

19 Cf. Josette Féral, "Foreword", in SubStance, issue 98/99, vol. 31, pp. 3-13.

20 In systems theoretical terms, this conception of theatricality leads our attention to questions about $A n$ schlussfähigkeit (connectability) (cf. Niklas Luhmann, Soziale Systeme, Suhrkamp Verlag, Frankfurt am Main 1984 , p. 123f), i.e. what possibilities for communication are made available/unavailable through a given mode of communication. This diverges from the partly coinciding concept of staging (cf. Martin Seel, Ästhetik der Inszenierung, Suhrkamp, Frankfurt am Main 2001), which instead addresses the intentionality of a given framing of communication.

21 This is an important precondition for a lot of theory in the field of applied drama, cf. for example Janek Szatkowski, "Rollespillets udfordring - udfordring til rollespillet” in Rollespil i astetisk, padagogisk og kulturel sammenhang, Anne Marit Waade, Kjetil Sandvik, eds., Aarhus Univeristy Press, Aarhus 2006, pp. 151-67.

22 Cf. Josette Féral, "Theatricality" in op. cit., p. $98 \mathrm{f}$.

23 Cf. Luhmann, Einführung in die Systemtheorie, op. cit., p. 233. "Sinn ist das Medium, das mit der Differenz von Aktualität und Potenzialität arbeitet, und zwar mit der Differenz, mit der Unterscheidung in dem Sinne, dass die Einheit der Unterscheidung immer mitspielt, dass man also immer in dem, was aktuell sieht, Möglichkeitsperspektiven hat und umgekehrt Möglichkeiten nicht thematisieren kann, nicht denken kann, auch gar nicht kommunikativ benutzen kann, wenn man dies nicht aktuell tut." ("Meaning is the medium which works with the difference between actuality and potentiality, and exactly with the difference, with the distinction in the 
sense that the unity of the distinction always plays along; you always have a range of possibilities through what you perceive as actuality, and in turn there are always possibilities which you cannot address, cannot conceive of, cannot use communicatively, when you are not actually doing it." My translation.)

24 The distinction between communication and consciousness as different (though structurally coupled) autopoietic systems is one of the basic premises of Luhmann's theory. Cf. Luhmann, Die Kunst der Gesellschaft, op. cit., chapter 1.

25 According to Wolfgang Iser: "Fiktion ist Form ohne Realität." (Wolfgang Iser, "Die Appelstruktur der Texte” in Rezeptionsästhetik. Theorie und Praxis, R. Warning, ed., Wilhelm Fink Verlag, München 1975 [1970], p. 231.)

26 Richard Schechner, Between Theatre and Anthropology, University of Pensylvania Press, Philadelphia 1985, p. 110.

27 Cf. Elena Esposito who presents a theory of fiction along the same lines: "Im Theater, und nur im Theater, kann (und muß) der Beobachter also beide Seiten des Problems sehen: Vorgetäuschtes und Tatsächliches - man denke nur an Shakespeare. In einer Welt, in der sich die Erscheinung von der Realität abgelöst hat, besteht der Realismus der Theatervorstellung gerade darin, diese Doppeldeutigkeit zu spiegeln, beide Aspekte darzustellen und sie für den Zuschauer sichtbar zu machen. In einer Welt, die immer undurchschaubarer wird, beruht die Realität der Fiktion gerade auf der Durchschaubarkeit der Täuschung. In den Begriffen der Systemtheorie handelt es sich um eine Beobachtung zweiter Ordnung, die die Realität der Welt um die Anzahl der Beobachterperspektiven vielfacht." (Die Fiktion der wahrscheinlichen Realität, Suhrkamp Verlag, Frankfurt am Main 2007, p. 17.)

28 This is a device we know very well from Body Art; for example, the work of Marina Abramovic, Chris Burden or Ron Athey. But here it is applied inside a very manifest theatrical framing that constantly suggests that what is going on is just a voluntary game; at the same time, this suggestion is constantly undermined by the concrete actions of the performers.

29 Cf. e.g. Signa Köstler: "A Letter from the Director" at http://villa-salo.dk/info.shtml (accessed 2 July 2015).

30 I attended the performance in October 2009. All quotations in this article are from the published text: Tim Crouch, The Author, Oberon Books, London 2009.
31 Rancière, op. cit., p. 13.

32 Cf. Contemporary Theatre Review, vol. 21, no. 4, 2011. In Tim Crouch's own contribution to the issue, pp. 416-22, he cites some of the letters of complaints he has received after the performance.

33 Michael Kirby, "On Acting and Not-Acting" in The Drama Review, vol. 16, no. 1, 1972, pp. 3-15.

34 Crouch, The Author, op. cit., p. 16, emphasizes in his note to the play that "The Author is set in the Jerwood Theatre Upstairs at the Royal Court Theatre - even when it's performed elsewhere". The situation of enunciation thus seems to be the strongest (and the most complex) when the play is performed at the Royal Court Theatre with Tim Crouch as its main character, otherwise the sliding between fiction and reality is cancelled out and we would be working with a more traditional kind of epic dramaturgy.

35 Rancière, op. cit., p. 4.

36 Slavoj Žižek, Living in the End Times, Verso, London, New York 2011 [2010], p. 55. Žižek - following Alain Badiou - distinguishes between constituted and constitutive ideology, the first relating to content and the second to form (the constitutive ideology being thus the implicit ideological coordinates of the space in which the content is located).

37 Cf. Erika Fischer-Lichte, Theatre, Sacrifice, Ritual: Exploring Forms of Political Theatre, Routledge, London, New York 2005.

38 Cf. Stephen Bottoms, "Materialising the Audience: Tim Crouch's Sight Specifics in ENGLAND and The Author" in Contemporary Theatre Review, vol. 21, no. 4, 2011, esp. p. 463.

39 Cf. Žižek, op. cit.

40 “"One should never hope for anything," said Pasolini. "Hope is a thing invented by politicians to keep the electorate happy." Is it hope that enables us to live on comfortably as witnesses of worldwide misery? Does change occur when hope is out? Or is that when the abyss will start gazing into us?” (Signa Köstler, op. cit.) 